\title{
The real potential of semen production of Bali Bull: over year observation at Singosari National Artificial Insemination Center (SNAIC), Singosari-Indonesia
}

\author{
Chairdin Dwi Nugraha ${ }^{1}$, Nashi Widodo ${ }^{2}$, Kuswati Kuswati ${ }^{1}$ and Suyadi Suyadi ${ }^{1, *}$ \\ ${ }^{1}$ Faculty of Animal Science, University of Brawijaya, Jl. Veteran, Malang 65145 - Indonesia \\ 2 Department of Biology, Faculty Mathematics and Natural Sciences, University of Brawijaya, Jl. \\ Veteran, Malang 65145 - Indonesia
}

\begin{abstract}
Increased reproduction is closely related to increased bull productivity. The high productivity of these bulls will increase the amount of straw. The productivity capability of Bali bull is essential in producing straw. High productivity will result in high straw production as well. So the research aims to determine the productivity of Bali bull at SNAIC in the last year. 31 Bali bulls aged $4-11$ years were used in this study at SNAIC. Total 1.273 ejaculations collection from these during one year. The parameters used in this study include the number of successful holding of each bull, total productivity, and estimation of straw production in one year. From 31 Bali Bulls, the ranking was grouped into two based on values of sperm productivity. The two groups were analyzed using an unpaired T-test. The results showed that the $\mathrm{pH}$, volume, individual motility, concentration, and abnormality were significantly different $(P<$ 0.05 ) between the high and low groups. The percentage of successful shelters, total TSM, and the number of straws produced in one year in the high productivity group were higher than the low productivity group. High productivity groups are the best with high productivity potential and potential as a source of semen.
\end{abstract}

\section{Introduction}

Bali cattle (Bos sondaicus) is one of the local cattle breeds with the highest population among other local cattle in Indonesia. Bali cattle are resistant to parasites and tropical environments in Indonesia and have better reproductive efficiency than other local cattle [1]. Bali cattle have been established through the Decree of the Minister of Agriculture No. $325 / \mathrm{Kpts} / \mathrm{OT} .140 / 1 / 2010$, as native Indonesian cattle and have an essential role in the national meat supply [2].

Superior bulls have been selected based on their lineage, production, and reproductive capabilities [3]. Good semen must be above the minimum standard of fresh semen to be processed into frozen semen. The minimum motility value is $70 \%$ [4], while the maximum

* Corresponding author: suyadi@ub.ac.id 
abnormality is $20 \%$, the volume ranges from $7-10 \mathrm{ml}$ with a spermatozoa concentration of $1000-1500 \times 10^{6} / \mathrm{ml}[5,6]$. Bull fertility is influenced by age, race, body condition, feed, ejaculation ability, and environment [7].

Efforts to develop and preserve Bali bull from all aspects need to be carried out sustainably. One crucial aspect of doing is to improve the quality of reproduction. Increased reproduction is closely related to spermatozoa fertility and increased bull productivity. Reproduction is an essential step in the management system that impacts the economic aspect [8]. The high productivity of these bulls will increase the amount of frozen semen production. The government regulation of the minister of agriculture No. 10/Permentan/PK.210/3/2016 in section 4, namely the provision of frozen semen for domestically produced ruminants, must be $60 \%$ from native and/or local ruminants. This is an excellent opportunity for Bali cattle if they produce higher productivity [9].

On the other hand, the quality of Bali cattle semen varies highly. For example, the motility value of Bali cattle in several studies includes $62.07 \% ; 70.00 \% ; 80.00 \% ; 89.62 \%$ [10 - 13].

The productivity capability of Bali cattle is essential in producing frozen semen. Productivity is closely related to the value of volume, individual motility, and concentration of spermatozoa. Higher productivity will result in high straw production as well. So the research aims to determine the productivity of Bali cattle at BBIB Singosari in the last year.

\section{Materials and methods}

\subsection{Animals}

The study was carried out at Singosari National Artificial Insemination Center (SNAIC), Singosari-Indonesia (SNI.ISO 90001:2015). A total of 31 Bali bulls aged 4-11 years were used in this study. Total 1.273 ejaculations collection of these during one year. The bulls were reared under similar management based on the standard procedure in SNAIC.

\subsection{Semen Collection and Evaluation}

Semen collection was conducted once a week every morning. Semen was collected using an artificial vagina as a Standard Operating Procedure (SOP) of the SNAIC. The artificial vagina type is Double-Walled type. Semen quality data were determined in laboratories through direct observation after semen collection. The microscopic evaluations were individual motility, sperm concentration, and viability. The macroscopic evaluations were volume, $\mathrm{pH}$, and color.

The volume of semen $(\mathrm{ml})$ is determined directly after the semen is stored on the scale of the tube used to hold the semen [5]. Individual motility (\%) was observed with a microscope with 400x magnification at a constant temperature using a cover glass, then determined the proportion (percentage) of progressively moving spermatozoa. The sperm concentration was observed by using a spectrophotometer [14]. Sperm viability used the eosin nigrosine staining method. The head of living spermatozoa will remain transparent and the dead spermatozoa will be red in color [15]. 


\subsection{Data Classification}

The total motile spermatozoa from each of Bali cattle for one year were calculated. The Total Spermatozoa Motil (TSM) value obtained becomes a reference for determining the rank of bull. Based on the productivity of Bali bulls in a year is obtained were divided into two groups. The top three bulls became the high group, and the lowest three bulls became the low group.

\subsection{Statistical Analysis}

From 31 Bali Bulls, the ranking was grouped into two based on values of sperm productivity. The two groups were analyzed using an unpaired T-test and were processed by using SPSS 24 . Data were presented with the mean \pm standard deviation (SD). Bull productivity was assessed from the Total Spermatozoa Motile using the following formula:

$$
\text { Total Spermatozoa Motile }=\text { volume } \times \text { concentration } \times \text { individual motility }
$$

Standard Operational Procedures (SOP) at SNAIC in a dose of 1 straw or $0.25 \mathrm{ml}$ total spermatozoa concentration are $25 \times 10^{6}$. So, the estimated number of frozen semen straws produced in one year is calculated by the formula:

$$
\text { Number of straws }=\text { Total Spermatozoa Motile } / 25 \times 10^{6}
$$

\section{Results and discussion}

Macroscopic examination (Table 1) showed that the $\mathrm{pH}$ and semen volume were significantly different $(P<0.05)$ between the high and low groups. The highest $\mathrm{pH}$ was in the low group, while the high volume was in the high group. The color of the semen of the high group was milk-white, while the low group was clear white. The range of semen volume ranged from 4.07-8.79 ml. Suyadi et al. [16] stated that the semen volume in Bali bulls was constant from 4.7 to $4.9 \mathrm{ml} /$ ejaculate. Semen volume increases with age [14]. This is because increasing age will cause the scrotal circumference to grow so that the volume of semen increases.

Table 1. Characteristics of Bali bull semen in the two productivity groups

\begin{tabular}{|c|c|c|}
\hline \multirow{2}{*}{ Parameter } & \multicolumn{2}{|c|}{ Productivity Group } \\
\cline { 2 - 3 } & High & Low \\
\hline N ejaculate & 141 & 67 \\
\hline Color & Milk White & Clear White \\
\hline $\mathrm{pH}$ & $6,49 \pm 0,40^{\mathrm{a}}$ & $6,62 \pm 0,22^{\mathrm{b}}$ \\
\hline Semen Volume (mL) & $8,79 \pm 1,68^{\mathrm{b}}$ & $4,07 \pm 1,15^{\mathrm{a}}$ \\
\hline Individual Motility $(\%)$ & $82,32 \pm 6,94^{\mathrm{b}}$ & $79,17 \pm 9,15^{\mathrm{a}}$ \\
\hline Sperm Concentration $\left(10^{6} / \mathrm{mL}\right)$ & $1320,21 \pm 292,95^{\mathrm{b}}$ & $757,49 \pm 369,54^{\mathrm{a}}$ \\
\hline Sperm Abnormality $(\%)$ & $4,40 \pm 2,31^{\mathrm{a}}$ & $10,37 \pm 6,38^{\mathrm{b}}$ \\
\hline
\end{tabular}

Different superscripts within line indicate significant differences $(\mathrm{P}<0,05)$ 
The results (Table 1) showed that microscopic examination (individual motility and concentration) of the high group was significantly $(P<0.05)$ higher than that of the low group. Meanwhile, the abnormality of the high group was lower than that of the low group. Individual motility ranged from $79.17 \%-82.32 \%$, sperm concentration per ejaculate was between $757.49 \times 10^{6}-1320.21 \times 10^{6}$, and sperm abnormalities were between $4.40 \%$ $10.37 \%$.

The average individual motility in this study was higher than that of Nugraha et al.[14] at $62.5 \%$ and Nugraha et al. [17] at $65 \%$, while a suitable bull for breeding must have an individual motility value of at least 70\% (SNI 4869-1:2017). Bali bulls in this study were included in the category of good semen quality, which was more than $60 \%-75 \%$ for sperm motility [5]. The sperm concentration in this study was lower than that in PO cattle [18], which was $2250 \times 10^{6} / \mathrm{mL}$ and higher than Madura bull that is $797.526 \times 10^{6} / \mathrm{mL}$ [19]. The semen of the Bali bull in this study is included in the criteria for good quality semen because the requirements for good semen are sperm concentrations of more than 500 million/ml [5]. At the same time, the abnormality is higher than Suyadi [16], which is $2.99 \%$. According to Ax et al. [5], good spermatozoa abnormality is less than $20 \%$.

Table 2. Number of semen successes that were successfully accommodated in two different TSM groups

\begin{tabular}{|c|c|c|c|c|c|}
\hline \multirow{4}{*}{$\begin{array}{c}\text { Productivity } \\
\text { Group }\end{array}$} & \multirow{2}{*}{$\begin{array}{c}\text { Bull } \\
\text { Code }\end{array}$} & \multirow{2}{*}{$\begin{array}{c}\text { Age } \\
\text { (year) }\end{array}$} & $\begin{array}{c}\text { Total Shelter } \\
\text { (ejaculation) } \\
\text { in 1 Year }\end{array}$ & \multicolumn{2}{|c|}{$\begin{array}{c}\text { Total Shelter (ejaculation) } \\
\text { Succeed in 1 Year }\end{array}$} \\
\cline { 5 - 7 } & & (times) & (times) & (\%) \\
\hline \multirow{4}{*}{ High } & Bull 1 & 10 & 47 & 47 & 100,00 \\
\cline { 5 - 7 } & Bull 2 & 10 & 47 & 47 & 100,00 \\
\cline { 2 - 7 } & Bull 3 & 4 & 47 & 47 & 100,00 \\
\hline \multirow{4}{*}{ Low } & Bull 29 & 4 & 47 & 18 & 38,30 \\
\cline { 2 - 7 } & Bull 30 & 6 & 47 & 42 & 89,36 \\
\cline { 2 - 7 } & Bull 31 & 10 & 47 & 7 & 14,89 \\
\hline
\end{tabular}

Table 2 shows that all bulls in the high group in one year were successfully accommodated 47 times out of a total of 47 shelters (ejaculation) carried out. While in the low group, no bulls were successfully accommodated 47 times in one year. Bull 29 as many as 18 times in a total of 47 shelters (ejaculation) a year. Bull 30 as many as 42 successful shelters (ejaculation) in one year. Bull 31 only seven successful shelters (ejaculation) in one year. Percentage of total shelter (ejaculation) succeed in one years in bull 29, bull 30 and bull 31 were 38,$30 ; 89,36 ; 14,89$, respectively.

The results of this study, bull 1 , bull 2 , and bull 3 , which are the high productivity group, are included in the category of superior bulls because the percentage of successfully accommodated reaches $100 \%$. This study shows that there is a wide variation in Bali bull at SNAIC-Singosari. This reflects the genetic diversity of the Bali bull, which still has the opportunity to be improved. [20] stated that the application of genetic standards needs to be considered to maximize the potential and maximum and sustainable sperm production. 
Table 3. The potential productivity of Bali bulls and the estimated number of straws produced in one year

\begin{tabular}{|c|c|c|c|c|c|}
\hline $\begin{array}{c}\text { Productivity } \\
\text { Group }\end{array}$ & $\begin{array}{l}\text { Bull } \\
\text { Code }\end{array}$ & $\begin{array}{c}\text { Age } \\
\text { (year) }\end{array}$ & $\begin{array}{c}\mathbf{N} \\
\text { ejaculate }\end{array}$ & $\begin{array}{c}\text { Total TSM in } 1 \\
\text { Year }\left(10^{6}\right)\end{array}$ & $\begin{array}{c}\sum \text { Straw generated } \\
\text { in } 1 \text { Year (straw) }\end{array}$ \\
\hline \multirow{3}{*}{ High } & Bull 1 & 10 & 47 & 501.803 & 20.072 \\
\hline & Bull 2 & 10 & 47 & 427.069 & 17.083 \\
\hline & Bull 3 & 4 & 47 & 408.973 & 16.359 \\
\hline \multirow{3}{*}{ Low } & Bull 29 & 4 & 18 & 67.688 & 2.708 \\
\hline & Bull 30 & 6 & 42 & 67.251 & 2.690 \\
\hline & Bull 31 & 10 & 7 & 37.213 & 1.489 \\
\hline
\end{tabular}

The potential for frozen semen production per ejaculation has a reasonably high range between the high and low groups. The potential for frozen semen production in the high group (Bull 1, Bull 2, and Bull 3) in one year were 20,072 straws, 17,083 straws, and 16,359 straws per ejaculate, respectively (Table 3). Meanwhile, in the low group (Bull 29, Bull 30, and Bull 31), the potential for frozen semen production was 2,708 straws, 2,690 straws, and 1,489 straws.

Bali bull productivity is closely related to the amount of straw produced. Potential productivity is the ability of each bull to produce straw or frozen semen. Productivity in this study is calculated for one year. The difference in straw production between the high and low productivity groups was caused by the number of successful collections in one year. In the low group, the moderate success per individual is only 22.3 times, while in the high group, the average success per individual reaches $100 \%$ or 47 times.

The results showed that the straw produced by each bull in the high group for one year was higher than Ditjennak [21]; which is, the minimum local bull each individual produced was 7,500 straws annually. The research results are also higher than those of other Bali cattle studies Indriastuti et al. [13], with 11,843.17 straws per year. This shows that Bali cattle at BBIB Singosari have the potential to produce high straw. The potential for frozen semen production is influenced by volume, concentration, and the number of motile sperm $[21,23]$.

\section{Conclusion}

Based on the number of successful shelters (ejaculation), the total TSM, and the number of straws produced in one year, it can be concluded that the two groups of high and low productivity in Bali bulls were different. Bull 1, Bull 2, and Bull 3 at SNAIC-Singosari are the best with high productivity potential and potential as a source of semen.

The author thanks the Director and Team of Singosari National Artificial Insemination Center (SNAIC)-Singosari, Malang-Indonesia for providing data of reproductive and semen quality for Bali bull. 


\section{References}

1. L. W. Pribadi, S. Maylinda, M. Nasich, S. Suyadi, J. Agric. Vet. Sci., 7 (2014)

2. Kementan (Kementerian Pertanian), Decree of the Minister of Agriculture Number 325/Kpts/OT.140/1/2010 Concerning Determination of Bali Cattle Clumps, Ministry of Agriculture (2010)

3. SNI - Standard Nasional Indonesia, Bibit Sapi Potong - Bagian 5: Bali, Badan Standardisasi Nasional SNI 7651.4:2017 (2017)

4. SNI - Standard Nasional Indonesia, Semen Beku - Bagian 1: Sapi, Badan Standardisasi Nasional SNI 4869.1:2017 (2017)

5. R. L. Ax, M. Dally, B. A. Didion, R. W. Lenz, C. C. Love, D. D. Varner, B. Hafez, M. E. Bellin, Semen Evaluation In: Reproduction in Farm Animal ed By Hafez ESE, 7th Edition (2008a)

6. R. L. Ax, M. Dally, B. A. Didion, R. W. Lenz, C. C. Love, D. D. Varner, B. Hafez, M. E. Bellin, Artificial Insemination In: Reproduction in Farm Animal ed By Hafez ESE, 7th Edition (2008b)

7. M. M. Rojas-Downing, A. P. Nejadhashemi, T. Harrigan, S. A. Woznicki, Clim. Risk Manag., 16 (2017)

8. S. Suyadi, L. Hakim, S. Wahjuningsih, H. Nugroho, Journal of Applied Science and Agriculture, 9 (2014)

9. Kementan (Kementerian Pertanian), Regulation of the Minister of Agriculture of the Republic of Indonesia Number 10/Permentan/PK.210/3/2016 concerning the Supply and Distribution of Ruminant Animal Frozen Semen, Ministry of Agriculture (2016)

10. S. Bayu, N. Isnaini, Russ. j. agric. soc.-econ. Sci., 2 (2020)

11. Yendraliza, A. E. Harap, J. Handoko, M. Rodiallah, Animal Science, 43 (2019)

12. Yendraliza, A. E. Harahap, J. Handoko, M. Rodiallah, C. Arman, Songklanakarin J. Sci. Technol., 42 (2020)

13. R. Indriastuti, M. F. Ulum, R. I. Arifiantini, B. Purwantara, Vet. World, 13 (2020)

14. C. D. Nugraha, E. Herwijanti, I. Novianti, A. Furqon, W. A. Septian, W. Busono, S. Suyadi, J. Indones. Trop. Anim. Agric., 44 (2019)

15. A. Budiyanto, M. Arif, M. P. W. Alfons, R. T. Fani, A. F. Hafid, B. Wicaksono, K. M. Insani, M. Herdinta, Acta Veterinaria Indonesiana, (2021)

16. S. Suyadi, E. Herwijanti, W. A. Septian, A. Furqon, C. D. Nugroho, R. F. Putri, IOP Conf. Ser. Earth Environ. Sci., 478 (2020)

17. C. D. Nugraha, E. Herwijanti, I. Novianti, A. Furqon, W. A. Septian, W. Busono, S. Suyadi, Journal of Tropical Animal Production, 20 (2019)

18. C.D. Nugraha, N. Widodo, Kuswati and S. Suyadi, IOP Conf. Ser. Earth Environ. Sci., 788 (2021)

19. I. Novianti, B. Purwantara, E. Herwijanti, C. D. Nugraha, R. F. Putri, A. Furqon, W. A. Septian, S. Rahayu, V. M. A. Nurgiatiningsih, S. Suyadi, Jurnal Ilmu-Ilmu Peternakan, 30 (2020)

20. S. Prastowo, N. Widyas, A. Ratriyanto, M. S. T. Kusuma, P. Dharmawan, I. A. Setiawan, A. Bachtiar, IOP Conf. Ser. Earth Environ. Sci., 372 (2019)

21. Ditjennak (Direktorat Perbibitan dan Produksi Ternak), Directorate of Animal Breeding and Production, Directorate General of Animal Husbandry and Health, Ministry of Agriculture (2018)

22. S. Aisah, N. Isnaini, S. Wahyuningsih, Indones. J. Anim. Sci., 27 (2017)

23. Santoso, Herdis, R. I. Arifiantini, A. Gunawan, C. Sumantri, Trop. Anim. Sci. J., 44 (2021) 